University of Warwick institutional repository

This paper is made available online in accordance with

publisher policies. Please scroll down to view the document

itself. Please refer to the repository record for this item and our

policy information available from the repository home page for

further information.

To see the final version of this paper please visit the publisher's website. Access to the published version may require a subscription.

Author(s): Matt McDonald

Article Title: Constructing Insecurity: Australian Security Discourse and Policy Post-2001

Year of publication: 2005

Link to published version: http://dx.doi.org/10.1177/0047117805055408

Publisher statement: None 


\section{Constructing Insecurity: Australian Security Discourse and Policy Post-2001}

Matt McDonald, University of Birmingham ${ }^{1}$

Forthcoming in International Relations, Vol. 19, No. 3 (September 2005):

For many, 2001 marked a watershed year in Australian foreign policy. It saw Australia reach international headlines for its hard-line stance on asylum-seekers in August, while the events of the subsequent month saw Australia's immediate (even enthusiastic) commitment to the war on terror and the US-led 'Coalition of the Willing' that was to take Australian troops from Afghanistan in 2001 to Iraq in 2003. Fundamentally, as Michael Wesley has argued, it was 2001 when 'Australia's relations with the outside world seemed to have changed from those of engagement and openness to watchfulness and security'. ${ }^{2}$ While Australia's approach to the issues of asylum-seekers and terrorism, and security more broadly, had origins that pre-dated the Tampa stand-off and the September 11 attacks, 2001 marks a useful starting point for an analysis of Australian security discourses and practices. These discourses and practices are significant not only in elaborating central dimensions of contemporary Australian foreign policy, but in reflecting on Australia's role in the de-legitimisation of human rights norms regarding asylum-seekers and the legitimisation of the war on terror and US foreign policy more generally. Given the dynamics of what might be called a 'race to the bottom' in asylumseeker policy in the West, ${ }^{3}$ and the scope and implications of US hegemony, these developments are important not simply in illuminating Australian foreign and security policy processes, but in illuminating important issues in contemporary international relations. Crucially, I argue, Australia's role in both of these developments can be understood within the context of the Australian government's understanding of, and approach to, security.

From 2001 to the present, security has generally been understood in statist, exclusionary and militaristic terms in the Australian context. These terms refer here to the centrality of the preservation of the state, rather than individuals within it (statism); the emphasis on achieving security against rather than with the other (exclusion); and the primacy of military responses to potential security 'threats' (militarism). Such a conception of security may be compared with alternative approaches to security emphasising an ultimate concern with individual emancipation or quality of life; with achieving security with rather than against the other; and with emphasising non-violent means of achieving security. ${ }^{4}$ While the former understanding of security has arguably dominated the way security has been understood in Australia and indeed globally for some time, the extent to which such a conception of security has captured the approach to security in the contemporary Australian political context is unparalleled in recent times and therefore requires some elaboration. To be sure, global events and processes (most notably the terrorist attacks in 2001 and 2002) are significant in understanding the prominence of this security conception, but I argue here that it is more important to analyse the ways in which the Australian government has given meaning to these events.

Since 2001 the Howard government has invoked security concerning issues marginally related (if at all) to traditional state security (asylum-seekers, for example) while also 
representing the threat posed by terrorism in such a way as to encourage a range of political responses that potentially undermine individual security (involvement in conflict in Iraq and the strengthening of domestic anti-terror legislation, for example). In short, the Howard government has played a crucial role in creating a context in which security is primarily understood as involving the (violent) rejection of ethical responsibility to the 'other', and the need for a militarised vigilance in protecting Australia's security in an insecure world. While the Australian government clearly is in a strong position to influence the way security is understood in the Australian context, however, the intersubjective nature of security means that there are always possibilities for change in the way security is understood and realised. This article will first outline the way in which security is understood and applied here, before addressing the Australian government's approach to the issues of asylum-seekers and terrorism (in 2001 and 2002), and finally identify immanent possibilities for the emergence of alternative, more normatively progressive, security discourses and practices in the Australian context.

\section{Security as Political Construction}

I argue here that it is imperative to conceive security as a fluid, social construction. By this account, security is not considered to have a given meaning that is fixed across time and space. This is not imply that security has no ontological content. Security may be defined, for example, as 'freedom from danger or harm' or 'the preservation of a group's core values'. Such a definition, however, tells us little about what 'danger or harm' might mean; which group needs to be protected; by whom or from what threats. Answering these more specific questions about security necessarily involves wedding the definition of security to a particular security discourse. ${ }^{5}$ For example, security could be defined as the territorial preservation of the state from external threats of a military nature, in a manner evocative of a realist security discourse. ${ }^{6}$ Security might also, however, be defined as the emancipation of individuals from unnecessary structural constraints, a definition consistent with the Critical Security discourse of security. ${ }^{7}$ Defining security, therefore, is an enterprise that involves making a series of assumptions (must frequently described in the language of the referent, agent and nature of threats), about the nature of world politics, the extent of ethical responsibility in global politics, what particular values are in need of being preserved and what particular ends should be sought. The realist and Critical Security discourses of security clearly encourage radically different approaches to the realisation of security in international politics, to the extent that achieving or advancing security defined in realist terms may be inimical to the realisation of individual ‘emancipation'.

In practice, actors in international politics consistently engage in debate about the meaning of security in particular contexts, and their practices evoke particular meanings or discourses of security in a variety of situations. The Australian government's approach to asylum-seekers, to be explored in more depth later, provides a useful insight into this process of contestation and part of the dynamic of 'securitization'. In 2001, the Australian government defined boatloads of asylum-seekers as potentially undermining Australian sovereignty, and discussed responses to the 'problem' of asylum-seekers using the language of 'border protection' and 'deterrence'. ' This conception of asylum-seekers 
positioned security in realist terms, wherein the nation-state was in need of being protected from external threats to its territorial integrity. Numerous domestic and international actors contested this conceptualisation of asylum-seekers, and indeed the Australian government had itself in the past dealt with similar boatloads of asylumseekers without evoking security in these terms and without denying their claims to seek asylum in Australia. ${ }^{10}$

A crucial question emerges when considering the example of Australia's recent approach to asylum-seekers: is there anything inevitable about conceiving of security in such terms (ie as requiring a militarised protection of the state from the threat posed by asylumseekers)? Might not security be defined in such a way as to prioritise the needs of asylum-seekers? If this were the case, it would certainly follow that the way Australia approached asylum-seekers would be markedly different. We need, therefore, to recognise that 'security' in any given context is a social construction: an intersubjectively arrived at series of choices about ethical responsibility, the nature of global politics and the relative priority to be given to different values. The important questions to follow from this acknowledgement then become: why is security conceived in these terms, and through what processes is security constructed in certain contexts? These questions are not simply important in understanding Australia's approach to asylumseekers or terrorism, or even the way in which security is constructed in the contemporary Australian context. They are important in opening up critical space to reflect upon the way security 'works' in international relations. ${ }^{11}$

Central to the construction of security in any context is the role of power, broadly defined. I am particularly concerned here with power defined in structural or discursive terms, referring to the ability to construct what constitutes 'common sense'. ${ }^{12}$ Certainly, this dimension of power intersects in important ways with others: those actors most capable of influencing the constitution of the 'common sense' of security are often those with a material power preponderance over other actors (and thus capable of directly silencing marginal voices) or who enjoy a position of accepted institutional primacy that serves to grant them political legitimacy and to influence what constitutes 'good behaviour' in international society. ${ }^{13}$

The role of states in international relations is particularly illustrative of intersecting dimensions of power. As RBJ Walker has argued, the role and legitimacy of states in international relations are underpinned by a 'common sense' wherein states are conceptualised as necessary and even inevitable forms of political community. ${ }^{14}$ In general, post-positivist literature in international relations has been particularly useful in pointing to the production of a 'common sense' about security and to the ways in which the choices underpinning particular security discourses are obscured to the point that the conflation of security with a security discourse is seen as natural or apolitical. ${ }^{15}$ As such, while security and action carried out in its name are often presented as natural or inevitable, this meaning of security is based on a series of (often obscured) choices and assumptions. Further, understanding how security has come to mean certain things in certain contexts requires an analysis of power relations (broadly defined) that enable 
certain meanings of security to come to prominence while marginalising other security conceptions and practices (along with the actors who promote them).

The Australian government has been central to the construction of security in the contemporary Australian context. For many, such a conclusion would seem obvious given the centrality of states in the international system, and the power that their elected representatives have in defining how security should be understood and realised. Ascribing necessary primacy to the security representations of state governments in the construction of security, however, obscures the inter-subjective nature of security while also falling into the trap of positioning states as the only form of political community or indeed as the only site of politics in international relations.

While governments do generally occupy a central position in the way in which security is conceptualised and addressed through states' foreign policy, for example, they are also constrained in the ways in which they can represent and practice security by both international and domestic forces, and by dominant conceptions of history, culture and identity within the state itself. ${ }^{16}$ As such, a state government does not have carte blanche to define security in any way it sees fit: it must be attentive to domestic and international forces lending themselves towards a particular security discourse. Crucially, the recognition of the need to ensure 'the consent, or at least some degree of acquiescence, by the population' ${ }^{17}$ for security discourses and practices means that governments looking to promote these discourses and practices need to go about creating a context in which such security conceptions and actions resonate with domestic populations. ${ }^{18}$ The constructed and inter-subjective nature of security means that governments must generally go about creating support for particular security conceptions and practices within the domestic population, usually in a manner that also resists isolating the international community. ${ }^{19}$

In creating support for particular security conceptions and practices, actors engage (relatively constantly) in a range of representational strategies that serve to position the group in need of being protected and to contest or marginalise other security discourses and the voices that advance them. The language used by actors is crucial in this political project. Language, as it is understood here, is not incidental to political practice: rather, it serves to construct social reality in powerful ways, often simultaneously opening up possibilities and closing off opportunities for particular forms or representations of political action. ${ }^{20}$ In focusing in particular on the role of the Australian government in constructing security in certain ways, the following analysis bears comparison in scope and content to Milliken's description of significative analyses of foreign policy discourses, which are concerned with 'analysing how an elite's regime of truth (makes) possible certain courses of action by a state...while excluding other policies as unintelligible or unworkable or improper'. ${ }^{21}$ More fundamentally in the context of this paper, though, the focus on the government's language is grounded in an overarching attempt to locate 'how, through a process of interaction, one type of context of another emerges'. ${ }^{22}$ As such, the emphasis on the role of language here combines post-structural concerns regarding power-knowledge relationships with constructivist concerns about the inter-subjective construction of social reality. 
Locating the way actors represent or evoke security through language is central not simply in illuminating how they approach security, but also in pointing to how they go about creating contexts in which certain security discourses resonate with domestic populations or with the particular group concerned. ${ }^{23}$ This need to ensure resonance is further underpinned by the centrality of security to the modern political project. As Michael Dillon ${ }^{24}$ has noted, the provision of security is the central determinant of a state's legitimacy in contemporary international politics. The importance of security in this context means that utterances of security may be read as legitimation practices on the part of states or as particular forms of representation that serve to order social reality in certain ways by defining the identity, values and aspirations of the group in need of being protected. ${ }^{25}$ Representations of security are, therefore, inherently political: they are based on a series of assumptions about the world and the group concerned, and they can serve to legitimise certain practices. It is in this context that the security representations of actors, most notably through language use, should be read.

This section has made five principal claims concerning the way security 'works' in international relations as a basis for the exploration of the construction of security in the contemporary Australian context. First, it is imperative to conceive of security as a fluid social construction, the meaning of which changes in different spatial and temporal contexts. The way in which security is understood, located here in particular discourses of security, is crucial in conditioning the practices that subsequently follow. Second, it becomes crucial (as a corollary to the above) to investigate the processes through which security has been constructed in certain ways. This also allows us to reflect on possibilities for the meaning of security to be changed in more normatively progressive ways. Third, and by way of a preliminary answer to the question of how certain discourses of security come to prominence, the role of power (broadly defined) is a central determinant of the meaning of security in particular contexts. The power enjoyed by states and their governments (founded upon structural, material and institutional bases) allows them a strong capacity to influence the construction of security. Having made this point, however, the fourth important point to note is that the inter-subjective nature of security and the centrality of security to the political project place limits on what political leaders can say and do in the name of security. As such, the political leaders of states must be attentive to dominant conceptions of security in the domestic population, and to other dimensions of influence operating through international pressure or domestic dissent, for example. Finally, language was noted here as an important political act, one that may demonstrate the conception of security held by a particular actor or allow for contexts to be created in which certain conceptions or practices of security are accepted or supported. These points provide us with an overarching conception of security as constructed, political, and susceptible to change.

\section{Security in Australian Politics}

On coming to power in Australia in 1996 the conservative Coalition government, led by Prime Minister John Howard, soon signalled a shift in the way security would be conceived and realised in Australian foreign and defence policy. Troubled by what they 
had perceived as the decline of the rightful primacy of the US alliance; an over-ambitious attempt to become part of the Asian region; and the limited capabilities of Australia's military to be deployed regionally or globally, the government began to emphasise almost immediately the need for a re-orientation of Australian security policy. In particular, the government indicated that it would seek to strengthen its bilateral security relationships, particularly with the United States, and that it would adopt a defensive policy of 'forward response', which would involve a 'greater emphasis on Australia's strategic strike and forward force-projection capabilities' and allow for the deployment of Australian forces to assist 'US forces in future military or peace-enforcement operations throughout the region' ${ }^{26}$ This policy of forward defence, announced in 1998, was criticised as ultimately positioning Australia as a 'regional deputy' to the United States, which some argued would serve to undermine Australia's regional relationships and give excessive ground to the foreign and security policy interests of the US. ${ }^{27}$ The government also sought to distance itself from the previous government's commitment to 'good international citizenship', which had positioned Australia's interests as being best served and advanced through commitment to the norms and rules of international society. ${ }^{28}$ The more narrowly defined conception of the national interest emphasised under the Howard government (evidenced in the title of its 1997 Department of Foreign Affairs and Trade White Paper, In The National Interest) arguably fed into a more 'narrow interpretation of Australia's security'. ${ }^{29}$

In general, a number of commentators described the government's approach to security prior to 2001 as an avowedly realist one, 'marked by a politics of exclusion'30 and centred on the territorial preservation of the Australian state from external military threats to Australia's borders. ${ }^{31}$ As such, the period from 2001 built in important ways upon the Howard government's conception of the world and Australia's place (and security) in it. Indeed, a similar interpretation of Australia's approach to security and defence was also made under the previous Labor government. ${ }^{32}$ Anthony Burke goes further in arguing that a perception of imminent external threats to Australia, encouraging a politics of exclusion in order to preserve a narrowly-defined and vulnerable Australian identity, has been an enduring feature of Australian foreign policy and of Australia's political leaders' perception of the world since the establishment of the Australian state. ${ }^{33}$

It is important, therefore, to recognise some level of continuity in the way security has been conceptualised and addressed in the Australian context. It would be a mistake, however, to understate the extent of the alteration in the ways and contexts in which the Australian government conceived of security from 2001. While building in important ways upon pre-conceived notions and interpretations of the national interest and indeed 'security', the events of 2001-2003 in particular allowed for a significant change in the way security was viewed in Australia. Among other developments, this period witnessed an unprecedented attempt to portray asylum-seekers as threats to Australian security and involved the first deployment of Australian troops without bipartisan support since the Vietnam War. It may indeed be argued that this period saw a general shift from a realist security discourse, invoked directly by the conservative Australian government at times, to one bearing significant resemblance to the neo-conservative conception of security in the United States, with its associated primacy of the global promotion of political and 
social 'values' and willingness to use force to achieve transformation in global politics. The two major statements on foreign policy published by the Coalition government, in 1997 and 2003, are instructive here. While the overview of the 1997 Department of Foreign Affairs and Trade White Paper emphasised the need to be realistic about the 'hard-headed pursuit' of Australia's national interests, for example, the 2003 White Paper's overview's first page was dedicated to the discussion of 'Australia's values', a

discussion that had been absent altogether from the 1997 document. ${ }^{34}$ Certainly, the emphasis on particularistic values and identity, combined with a politics of fear, was central to the Australian government's approach to questions of both asylum-seekers and terrorism from 2001.

\section{Asylum-seekers and Australian Security}

In August 2001, a Norwegian cargo ship, the MV Tampa, answered a distress call made by a sinking fishing boat outside Australian territorial waters. The Tampa diverted course and rescued 433 people who had been aboard the vessel, all of whom were aiming to reach Australia in order to seek asylum. After originally aiming to return to Indonesia (from where the asylum-seekers had embarked), the Tampa made towards the Australian territory of Christmas Island. Before it could reach the island, however, the Australian government issued an order for the Australian navy to intercept the Tampa and to prevent it from docking on the island (which would have obliged the Australian government to process the claims of the asylum-seekers). A two week stand-off between the navy and the Tampa followed, in which period the Australian government fully enunciated a commitment to prevent asylum-seekers from entering Australian waters illegally. Indeed, the government's subsequent approach to asylum-seekers attempting to reach Australia's migration zone by boat saw a continuation of the principles it elaborated, and the stand it took, regarding the Tampa.

Using Australia's approach to asylum-seekers as a basis for investigating the construction of security in the contemporary Australian context might appear somewhat unusual, given its superficial marginality to the focus of traditional security policy and analysis. A number of points are worth noting here, however, in underscoring the relevance of this example to security. First, the language the government used in defining its approach to asylum seekers demonstrated that as far as the government was concerned, the issue of illegal entry of asylum-seekers was a security issue. As Don McMaster notes, 'maintaining national sovereignty and security and protecting Australia's borders were the reasons given for the government's hardline policy towards the Tampa asylumseekers'. ${ }^{35}$

Second, the relationship between Australia's approach to asylum-seekers and security may be viewed in the deployment of military resources and personnel to 'protect' Australia from the threat posed by the asylum-seekers. This is an important point if, as Didier Bigo argues, ${ }^{36}$ the actions of security 'professionals' such as military personnel play a role not simply in realising security policy, but in influencing the way in which security is perceived and constructed in the broader political community. The deployment of military resources in this sense can be viewed as significant given the meaning 
portrayed to the Australian population: of the need for Australia's defence forces to protect the borders of the Australian state (and indeed islands in its migration zone) from violation. Finally, and most directly, the government invoked the tragic circumstances of September 11 (which occurred while the furore over the Tampa was ongoing) to justify its approach to asylum-seekers and migration policy in general. For a number of government ministers, and for Prime Minister Howard himself, the events of September 11 underscored the need for vigilance about migration practices and even raised the spectre of terrorists hiding themselves among asylum-seekers attempting to reach Australian territory. ${ }^{37}$ The conflation of these two concerns (border protection and terrorism) may be viewed here as a particularly important representation on the government's part: of demonstrating a particular conception of security and serving to create a context in which its policy on asylum-seekers was even more acceptable to the Australian population. These points, particularly the way in which this security discourse was evoked and a relationship between asylum-seekers and terrorists was drawn, require some elaboration.

From the outset, the Australian government articulated the view that the issue of asylumseekers arriving by boat was a security issue, particularly in terms of the threat posed to the sovereignty and territorial integrity of the Australian state. Prime Minister Howard argued at the time that:

It is in the national interest that this vessel not be allowed to stay in Australian territorial waters...It is in the national interest that we have the power...to prevent, beyond any argument, people infringing the sovereignty of this country. ${ }^{38}$

This conception of the problem of asylum-seekers was reiterated by other senior ministers in the Howard government. Foreign Minister Downer noted that 'at the heart of this (the Tampa issue) is the protection of our territorial integrity', ${ }^{39}$ while Defence Minister Peter Reith noted that 'if you can't control who comes into your country, that is a security issue'. ${ }^{40}$ Immigration Minister Phillip Ruddock echoed the concerns underpinning the formation of the Immigration Restriction Act (known popularly as the White Australia Policy) at the turn of the twentieth century in arguing that Australia could be 'overrun with large numbers of asylum seekers'. ${ }^{41}$ All of these representations served to position asylum-seekers as violating Australian sovereignty, undermining the security of the Australian state, and ultimately involved denying ethical responsibility to those outside of Australia's borders. The government also frequently invoked the strategic language of deterrence in arguing that its approach to the issue would send a message to would-be people-smugglers and asylum-seekers that Australia was not a 'soft touch'. This language may also be viewed as an attempt to influence the way Australians thought about asylum-seekers: as 'others' seeking to exploit the good will of the Australian people.

The events of September 11 saw the most direct attempts on the government's part to position asylum-seekers as threats to Australian security. Defence Minister Reith argued that the open entry of asylum-seekers could allow for a 'pipeline for terrorists to come in and use (the) country as a staging post for terrorist activities'. ${ }^{42}$ He also argued that the evens of September 11 made him 'determined to have an immigration program which the 
government is able to conduct with integrity'. ${ }^{43}$ A government member of parliament, Peter Slipper, went further in stating that there was:

An undeniable link between illegals and terrorists...Many of these illegals come from Afghanistan (and) it is not beyond the realms of possibility that some people gaining illegal entry into Australia this way are people who have been involved in terrorism or who do represent a threat to this country. ${ }^{44}$

While Prime Minister Howard noted that he did not want to 'exaggerate links between terrorism and illegal immigration', he also stated that on 'the question of character background of some of the people who have sought to come to this country illegally, the evidence is mixed. Some of them have criminal records'. ${ }^{45}$ He further noted that in the wake of September 11, Australia had a redoubled obligation to check who was entering the country. ${ }^{46}$ Given the extent of public concern about the threat of terrorism postSeptember 11, such a representation may be seen as particularly significant in both enabling the government to pursue its asylum-seeker policy with widespread public support, and furthering a particular conception of security in which Australia needed to be protected from the threat posed by asylum-seekers.

\section{Asylum-Seekers, Security and Contestation}

Of course, the government's approach to asylum-seekers was, as security always is, contested by a range of actors both domestically and internationally. A range of actors on the international stage (including individual states, NGOs and the UN High Commission on Refugees) argued that the Australian government's position revoked core norms and rules of international society, particularly regarding human rights. ${ }^{47}$ This arguably positioned the individual security of asylum-seekers as pre-eminent in considerations of how states should respond to this issue itself. A number of analysts and critics also pointed out that in spite of a developing international consensus on the need to address the problem of people-movements at its origins rather than through preventing them access, ${ }^{48}$ the Australian government seemed committed to the latter strategy, reflecting a concern only with protecting Australia from asylum-seekers rather than addressing the problem of asylum-seekers. McMaster argues that this was reflected in the government's expenditures in dealing with asylum-seekers. He notes that predictions of the government's spending on 'locating, removing and detaining asylum-seekers' in 2002 were in excess of \$200 million, compared with 'only around \$14 million to the UNHCR refugee fund' in the same year. ${ }^{49}$ Opposition political parties made similar points in domestic political debate. ${ }^{50}$

Other critical voices described the government's position as a populist one, playing upon fears in the electorate about a 'flood of refugees' in order to shore up domestic support for its approach and for the government in general. ${ }^{51}$ Opposition and minor political parties noted the significance of the timing of the Tampa crisis in this context: weeks before a federal election at a time when the government was behind in opinion polls. ${ }^{52}$ The timing and nature of the government's approach was also a basis for criticism given that immigration issues had traditionally been kept out of the public domain given the divisive nature of these concerns, and that (despite the language of the government) the 
numbers of those reaching Australia by boat was relatively small in a global context. ${ }^{53}$ Australian Democrats leader Natasha Stott-Despoja argued that 'the opportunity to link terrorism and boat people and to create unnecessary fear and distrust in the Australian population towards asylum-seekers (was) apparently electorally irresistible to some members of this government'. ${ }^{4}$ These criticisms involved a direct attempt to argue that the government was representing security in a particular way: one that was statist, exclusionary and excessively concerned with reactive and aggressive responses to political problems for the benefit of the government itself. ${ }^{55}$ Such criticisms may also be viewed as an acknowledgement of the role of security as a legitimating strategy, in the sense that these critics recognised the potential (electoral) benefit of invoking security regarding this issue.

The Australian government responded to many of the concerns noted above by reiterating their ultimate concern with Australian security and Australia's national interests, and (significantly) by portraying critics as un-Australian, unconcerned about Australian sovereignty and security and even as sympathetic to the motives of terrorists. The government responded to international criticism by invoking sovereignty and portraying Australia as being victimised by the international community. Foreign Minister Downer argued that 'whatever the rights and wrongs of these issues, we will decide them ourselves, not have bureaucrats in Geneva decide them for us' ${ }^{56}$ Prime Minister Howard also criticised the UN, noting that 'it seems in the eyes of some on the United Nations that the really democratic countries in the world are easy game for attack' ${ }^{57}$ Strongest criticism was perhaps reserved for critics at the domestic level, however. A government member of parliament accused the opposition, who had blocked legislation aimed at excising territories from Australia's migration zone, of not having '...any national spirit; they do not want to support this country'. ${ }^{58}$ Another member of parliament noted that the opposition was 'not standing up for national sovereignty'. ${ }^{59}$ A minor party representative also noted that she (and others in her party opposing the government's wide-ranging legislative responses to asylum-seekers) were accused by members of the government of 'not sympathising with victims (of September 11) and having sympathy for terrorists'. ${ }^{60}$

Describing those opposed to the government's policy on asylum-seekers as unconcerned about Australian national interests or even being 'un-Australian' may be viewed in two ways: either as an attempt to marginalise these voices from the policy process and the construction of security by portraying them as unconcerned about the nation's core values and interests; or as a form of what Bially Mattern describes as 'representational force', which enables the 'user' to 'bluntly, self-interestedly and non-negotiably compel his victim to abide by his version of some contested story'. ${ }^{61}$ In many ways, the government's representation of critics of its approach as 'un-Australian' bears resemblance to its depiction of asylum-seekers themselves: as others of whom Australia was in need of being protected. The depiction of asylum-seekers as others was particularly apparent in the government's erroneous claims that subsequent asylumseekers had risked the lives of their children by throwing them overboard, ${ }^{62}$ and its claim that the asylum-seekers were 'queue jumpers'. ${ }^{63}$ It was also evident in the government's use of the term 'illegals' to describe asylum-seekers arriving by boat, and arguably in its refusal to allow media outlets to photograph asylum-seekers, a policy some argued was 
designed to prevent 'humanising images' of asylum-seekers from being published. ${ }^{64}$ Crucially, the government's representations of both asylum-seekers and critics of its approach indicated a desire to marginalise those critical voices and foreclose opportunities for empathy for asylum-seekers to develop in the wider Australian population.

The Australian government received widespread public support for its approach to the issue of asylum-seekers from 2001, which was most explicitly captured in dynamics concerning the asylum-seekers on board the Tampa. National opinion polls indicated that a vast majority of Australians supported the government's stance, ${ }^{65}$ and the government's subsequent federal election victory was viewed by many as a vindication, if not a direct result, of its approach to this problem and its associated conception of security. ${ }^{66}$ Some argue that the support for the government's policies here was the result of its success in tapping into a darker element of Australian identity, ${ }^{67}$ while for others the success of the government in capturing the way security was conceptualised and addressed in this context was primarily owed to 'the Australian people (becoming) conditioned to fear the arrival of asylum-seekers', 68 a project furthered by the government's conceptualisation of this issue.

Certainly, the government's misrepresentation of asylum-seekers as potential terrorists, and its false claim that asylum-seekers had thrown children overboard, seem to validate the argument that the Australian government's representations of the issue were aimed at, and ultimately successful in, enabling its policy approach and in constructing security in certain ways. Its portrayal of critics of its approach as 'un-Australian' and as attempting to undermine Australia's sovereign rights may also be viewed here as an attempt to marginalise these actors from the construction of security, and to maximise the resonance of its own security discourse within the Australian population. These dynamics, and the government's commitment to this particular conception of security, were furthered by the terrorist incidents of September 11 and Bali, and again evident in the government's approach to conflict in Iraq.

\section{Terrorism and the War in Iraq}

While the Tampa situation may be viewed as a constructed security crisis in many ways, it would seem that the terrorist attacks on September 11, 2001 and in Bali in October 2002 constituted a material change in the global and regional security environment for Australia. Indeed, this was precisely how the Prime Minister represented these events: as signalling that Australia was confronted with a 'new and very dangerous security' environment. ${ }^{69}$ While recognising the scope and significance of these events, however, it is still important to reflect on the ways in which they were interpreted, represented and acted upon in an Australian context.

As noted, the September 11 terrorist attacks in the United States coincided with continuing furore over the government's approach to the Tampa asylum-seekers in 2001. In many ways, the Australian approach to September 11, and particularly to the subsequent US-led 'war on terror', saw a continuation of a conception of security defined 
in statist, exclusionary and militaristic terms. 22 Australians were killed on September 11, and there was a significant emotional response within Australia to images of the attacks and their aftermath. ${ }^{70}$ The immediate response of the Australian government was to condemn the attacks as acts of 'barbarism', a sentiment echoed throughout the world. More significantly in the context of this paper, the Australian government pledged support for the US military response within three days of the attacks and before a clarification of the specific target of the military response. In doing so, the Australian government invoked the 1951 ANZUS treaty, which was the first time either the United states or Australia had invoked the treaty 'to justify any form of military cooperation'. 71

At the domestic level, the Australian government sought to portray the attacks on September 11 as an attack on the values shared by Australians and Americans, and in a manner that positioned Australia's subsequent military role in intervention in Afghanistan as an act of self defence. Prime Minister Howard argued that the September 11 terrorist action constituted 'an attack on the way of life we hold dear in common with Americans'. ${ }^{72}$ He later argued that:

If we left this contest [the war on terror] only to America, we would be leaving it to them to defend our rights and those of all the other people of the world who have a commitment to freedom and liberty. We will not do that...Australians have always been a people prepared to fight their own fights. ${ }^{73}$

Such a representation, of the war on terror as an act of self-defence, may be viewed as an attempt to legitimise a military intervention to the Australian population. The Australian government initially deployed 122 troops to Afghanistan in the subsequent 'war on terror' without a public announcement, and by the end of the conflict in Afghanistan had sent 1550 troops, eight military and support aircraft, two frigates and an amphibious command ship. Such a commitment was arguably not central to the success of the military mission, but was significant in demonstrating the extent of Australia's commitment to the 'war on terror' and, more directly, its commitment to the United States. $^{74}$

In October 2002, a terrorist attack on the Indonesian island of Bali seemed to validate concerns about the potential for terrorism to spread globally, and particularly into Australia's region. 202 people were killed in this terrorist attack, which was carried out by Asian-based radical Islamic group Jemaah Islamiah, a group with suspected links to Al-Qaeda. Of the 202 dead, 88 were Australians, which meant that more Australians were killed in this attack than had been killed in all terrorist incidents since $1915{ }^{75}$ Coming a little over a year after September 11, the primacy of security concerns associated with violent threats to Australia and Australians may have been inevitable in political discourse and in the way in which security was conceptualised and addressed in the Australian context. In fact, it may be argued that the Australian government was compelled to respond aggressively to Bali, given the extent of public anger over this tragic event. It is worth reiterating here that it is possible to conceive of security as constraining: as placing limits on what political leaders can do based on dominant concerns within the broader domestic populace. While an important acknowledgement, it is also imperative to recall that security can be enabling: if a political leader, for example, 
can convince a domestic population that particular actions serve the end of 'security', those actions may subsequently be enabled or legitimised. It is in this context that it is imperative to reflect on the ways that meaning was given to this event (and September 11) by the government in conditioning the way security was conceived in the broader Australian context.

In responding to the Bali bombing, Prime Minister Howard argued that this terrorist attack underscored the need to expand Australia's military capacity in order to best ensure Australian security. He noted that 'I think it is inevitable (post-Bali) that we will have to spend even more on defence...that's just inevitable'. ${ }^{76}$ This particular representation may be viewed as an example of the ways in which a particular interpretation of an event/ problem (ie that terrorism requires aggressive, military responses to defeat it) can be cast as apolitical, inevitable, or as 'common sense'. This is a powerful representational strategy, one that masks a particular interpretation and particular assumptions about what security means and how it can be realised in the language of inevitability.

More significant in terms of the meaning given to the Bali bombings was the government's attempt to link the bombings themselves with the imperative for Australia to militarily support US intervention in Iraq. While the bombings came several months before Australia officially committed troops to the US-led Iraq intervention in March 2003, the Australian government had made it clear prior to Bali that it supported the US stance on Iraq, ${ }^{77}$ allowing for criticisms that Australia's position on Iraq had made Australians the target of terrorists. While the Australian government played down the extent to which there was a relationship between the Bali bombings and its stance on Iraq in this sense, it did argue that the events of Bali underscored the need for intervention in Iraq. At a direct level, the Trade Minister Mark Vaile speculated about the possible involvement of the Iraqi regime in the Bali bombings, in spite of any evidence to support this claim. ${ }^{78}$ Less directly, the government sought to advance the argument that rogue states such as Iraq could sell weapons of mass destruction to terrorists, thereby increasing the potential for greater carnage in future terrorist attacks. ${ }^{79}$ The Prime Minister went further in arguing, prior to officially committing Australia to intervention and in the face of significant domestic opposition to Australian involvement, that:

We lost 88 Australians in Bali because of a wilful act of international terrorism....and I will, amongst other things, be asking Australians to bear those circumstances in mind if we become involved in military conflict with Iraq. ${ }^{80}$

Such a representation may be viewed as an attempt on the government's part to play upon popular concern about terrorism in the wake of Bali in order to justify intervention in Iraq. Fundamentally, then, such a representation can be seen as an attempt to construct public support for an aggressive response to the (possible) development of weapons of mass destruction in Iraq. Australia's support for the war in Iraq was, I argue here, inseparable from the primacy of the US alliance in the Australian government's security outlook, ${ }^{81}$ one underpinned by a conception of the world in realist terms.

Terrorism, Intervention in Iraq and Contestation 
Critical responses to the government's security discourse regarding terrorism were somewhat circumscribed by the tragedy of events on September 11 and in Bali. Indeed, as Williams argues, 'it was difficult for the Opposition Labor Party's leaders to question (the government's) counterterrorism measures without seeming unpatriotic or not having the best security interests of the nation at heart'. ${ }^{82}$ The government, as will be noted, played an important role in constructing perceptions of opposition in this way. In spite of these limitations, a number of actors contested the way in which the Australian government had represented security and Australia's national interests in terms of the meaning it gave to events on September 11, in Bali and regarding the war in Iraq. A range of analysts noted that Australia's over-arching commitment to the US approach to the 'war on terror' could potentially undermine Australia's regional relationships. ${ }^{83}$ This is a particularly significant criticism given the apparent imperative of cooperating with states such as Indonesia over asylum-seeker movements and responding to terrorism.

Other critics of the government's response to terrorism noted that to the extent that Australia did pursue diplomatic and law-enforcement cooperation with the Indonesian military over terrorism, this involved working with the Indonesian military's (TNI) antiterrorist group, Kopassus, a group widely criticised for their role in human rights violations in Aceh. ${ }^{84}$ In the context of its commitment to the broader war on terror, still others argued that Australia might have used its close relations with the United States to encourage it to pursue more fully multilateral responses to terrorism, and combine its aggressive military approach with more diffuse and long-term actions to eliminate future threats of terrorism. ${ }^{85}$ Such a criticism positioned Australia's militaristic response to terrorism as a particular choice based on a particular interpretation rather than an inevitable course of action. For other critics of the government, the government's depiction of the evil regimes in Afghanistan and Iraq threw into stark relief its hardline approach to asylum-seekers, a significant percentage of whom were fleeing persecution in these countries. ${ }^{86}$ Jim George, meanwhile, argued that Australia's role in the war on terror and in Iraq, along with the 'militaristic mind-set associated with it', was 'likely to provoke the very instability and disorder it ostensibly (sought) to quell, thus increasing regional and global insecurity' ${ }^{87}$

A number of actors also pointed to the particular representational strategies of the government in responding to terrorism, arguing that the Australian government was attempting to 'use' terrorism to further justify a militaristic, statist and exclusionary approach to security. Opposition political parties, political commentators and parents of children killed in the Bali bombings argued that the Howard government was cynically attempting to exploit the deaths of those killed in Bali in order to justify intervention in Iraq. ${ }^{88}$ Others argued more generally that the Howard government was attempting to augment fears of terrorism to enable not only intervention in Iraq, but also to justify controversial domestic anti-terrorism legislation and even to further its own electoral support. ${ }^{89}$ At this level, it was not simply the security discourse and the course of action to which the Australian government was committed that was a basis for criticism, but also the ways in which the Australian government sought to create support for these actions and to engender support for the government itself. 
The responses of the Howard government to such criticisms bore significant resemblance to its response to criticisms about its actions regarding the Tampa. It sought to once again marginalise critics based on their lack of concern about Australian security and Australians generally. On the question of whether Australia's support for war in Iraq had made Australia more of a target for terrorists, the Prime Minister positioned critics as not standing up to the perpetrators of wrongful acts, arguing that history showed that no state could 'buy itself permanent protection (by) speaking softly of evil'. ${ }^{90}$ The Prime Minister also responded to criticisms from the Opposition that the government was trying to use Bali to justify Iraq in arguing that:

This [Bali] is an event that has horrified Australians beyond the partisan political divide and what they want of their political leaders right now is a united cohesive response and they will have no patience with the use of this issue for partisan political remarks. ${ }^{91}$

Such a representation of the Opposition's criticisms not only served to draw attention away from the government's invocation of the Bali tragedy to justify intervention in Iraq, but also served to question the motives of critics and the extent to which these critics were concerned with the well-being and security of Australia and Australians.

The government also targeted international actors in its attempt to further domestic support for its stance and in its attempt to marginalise those critical of Australia's militaristic approach to Iraq. Aware of the importance of the UN position on intervention in Iraq for the extent of support Australian military involvement could expect domestically, ${ }^{92}$ Prime Minister Howard sought to denigrate those actors standing in the way of a Security Council resolution, questioning their motives for opposing a resolution enabling UN action. He argued that:

We won't achieve...peaceful disarmament [of Iraq] if we continue to have spoiling tactics from, say, the French, who appear intent on saying no to everything irrespective of its merit... I think France has always regretted the... absolute rise of the United States as the pre-eminent world power. ${ }^{93}$

He went further still in arguing that 'appeasing' Iraq bore resemblance to the appeasement approach taken to Nazi Germany prior to World War II, ${ }^{94}$ and in arguing that the very credibility of the United Nations was at stake regarding Iraq:

If the Security Council doesn't pass the resolution I think it will have failed a test. If it... allows Iraq to get off the hook about disarming, it's seriously going to damage its credibility. ${ }^{95}$

These representations of the reality of the world and Australia's role in it after September 11 and the Bali bombings may all be viewed as attempts to portray a militaristic and aggressive response to terrorism as the only legitimate way in which Australia could be protected and could respond to the new and 'dangerous' security environment. This spilled over, for the government, into a justification of intervention in Iraq and an implicit criticism of those opposed to intervention as placating or tolerating 'evil', or being 
unconcerned about Australian (or indeed global) security. While the government's intervention in Iraq took place in the face of continued domestic political opposition, ${ }^{96}$ political commentator Denis Shanahan argues that the government ultimately wore down opposition to its stance after the deployment of troops, ${ }^{97}$ in part through representing the conflict as an attempt to rid the world of the evil of Saddam Hussein and also through arguing that Australians should support the troops who were putting their lives at risk to achieve this end. ${ }^{98}$ Indeed, Shanahan argued that in this context, 'Howard has driven the polls' ${ }^{99}$ This process may also be described as the successful creation of a context in which the government's actions, and its associated discourse of security, resonated with the Australian population.

\section{Towards an Alternative Security Discourse?}

The preceding analysis is not to suggest that all individual policies or events are interpreted by the government solely according to this statist, exclusionary and militaristic conception of security. It was, after all, the same Australian government that had led an intervention/ peacekeeping force in East Timor in 1999, and the same government that at the time of writing had outlined a $\$ 1$ billion assistance package to the Indonesian government in response to the horrific effects of the tsunami at the end of 2004. Neither of these policies would suggest a government devoid of compassion in its external relations. In recognising these exceptions to the generally militaristic, statist and exclusionary conception of Australian security held by the Australian government, it is worth noting that while core themes may exist no single security discourse ever completely captures the way a particular political community conceives of itself and the world around it.

When combined with limited but nevertheless progressive changes in asylum-seeker policy in 2003 and $2004,{ }^{100}$ these examples serve to remind us that there are always possibilities for change or exceptions to broader patterns of foreign and security policy. This, in turn, should encourage us to investigate more fully the conditions in which alternative security discourses and practices become possible. Crucially, public mobilisation has been central to the government's policies on all of these issues, although (significantly) in areas in which US foreign policy imperatives were not implicated. This latter point is an important caveat to note, particularly given that the belief in the need for this alliance has even led to the government commenting on its lack of choice on issues such as Iraq, wherein Australian involvement was conceptualised as necessary to maintain the alliance and therefore ensure the security of Australia and Australians. ${ }^{101}$ Once again, this range of factors remind us of the need to conceive of security as enabling and constraining, and to view future security prospects in terms of both opportunity and limits.

The difficulty in relying upon public mobilisation or concern to force progressive changes in security conceptions and practices rests on a number of bases. First, while focusing in this analysis on the role of the Australian government, numerous other influential actors have echoed and/or supported the government's position on issues such as asylum-seekers and terrorism, ${ }^{102}$ a situation making the emergence and resonance of 
marginalised and progressive voices on these issues all the more difficult. Second, and related to the proceeding point, public opinion may support statist, militaristic and exclusionary practices, as was the case concerning Australia's approach to asylumseekers. That this public opinion or support for the government's position may be constructed, and that it does not preclude the possibility of alternative practices emerging, does not negate the fact that public opposition may be an important immediate obstacle to the emergence of more normatively progressive security conceptions and practices. Finally, on some issues the government has proved singularly unwilling to allow public opposition to alter its preferred policy options. This has particularly been the case regarding commitment to the war in Iraq.

There are, nonetheless, immanent possibilities for change in the way in which security is conceived, located largely in the marginalised voices contesting government policy and pointing to the inherent inconsistencies in the government's approach. The empowerment of these voices is central to recognising possibilities for progressive change, as the example of change in asylum-seeker policy demonstrates. On issues relating to asylumseekers, for example, critics have pointed variously to Australia's limited financial commitment to the UNHCR relative to expenditure on interception and incarceration of asylum-seekers; to its portrayal of asylum-seekers as potential terrorists in spite of the absence of evidence to support this claim or the fact that many asylum-seekers are fleeing countries who the government itself has described as 'evil'; and to the fact that in the past, the Australian government had responded to influxes of asylum-seekers (Indochinese refugees in the 1970s, for example) without recourse to the language of border protection and security. ${ }^{103}$ Similarly, on the issue of Australia's response to terrorism, critics have noted that Australia's approach to the war on terror risks alienating regional neighbours; fails to recognise or engage constructively with the sources of terrorism; and even makes Australia and Australians more of a target for terrorist activity, a claim supported by reports from the government's chief intelligence body, ASIO, regarding Australian involvement in Iraq. ${ }^{104}$ Some critics have also argued that on these issues, the government has engaged in the politics of fear in order to create support for pre-determined policy preferences and to contribute to the legitimacy of the government itself. $^{105}$

While arguably having little immediate influence on the way security has been conceptualised and addressed in the contemporary Australian context, acknowledging alternative voices is in itself important, particularly if security is, as I have argued it should be, conceived as an inter-subjective construction. Once we acknowledge the intersubjective nature of security, we allow ourselves to recognise the importance of a range of actors to the security project, and the inherent possibility for change in the meaning associated with security. When combined with the more tangible implications of Australian security policy (such as increasing damage to Australia's international reputation; the failure to locate WMD in Iraq; and the continued and mounting casualties there), marginalised voices promoting alternative security discourses may provide the bases for changes in the way in which security is understood and practiced in the Australian context, even in spite of the re-election of the Howard government in October 2004. 
Security policy is a site of contestation between different groups who hold often radically different conceptions of which values and actors are in need of protection, by whom, through what means and from what threats. Some actors, such as the Australian government, possess greater capacity to influence the way security is conceptualised and addressed, leading some to lament the inevitability of security being constructed in such a way as to serve the interests of the powerful. ${ }^{106}$ While focusing on the role of the Australian government in constructing security in the period in question, this article has also sought to point to immanent possibilities for progressive change, largely through an immanent critique of the government's approach to security and through identifying marginalised actors contesting the government's security narrative. The Australian government's security approach is far from inevitable or necessary: it is, rather, constituted by a series of choices based upon a particular interpretation of Australian security, one which can be contested and should be acknowledged as an interpretation rather than a depiction of, or response to, a global 'reality'. This inherently contestable nature of security points to possibilities for a movement towards an alternative conception of security, one which is not based on assumptions about the ubiquitous nature of threats to Australia's sovereignty and territorial integrity, which does not encourage a denial of ethical responsibility to the vulnerable beyond the borders of the Australian nation-state, and which rejects the primacy of violent means of achieving 'security'.

\section{References}

\footnotetext{
${ }^{1}$ An earlier draft of this paper was presented at the International Studies Association conference in Montreal, Canada, March 2004 and the Oceanic Conference on International Studies in Canberra, Australia, July 2004. For their insightful comments on an earlier version of this paper, I am grateful to Anthony Burke, Kath Gelber, Lee Jarvis, Katrina Lee Koo, Richard Mills, Marc Williams and the two anonymous reviewers of this journal.

${ }^{2}$ M. Wesley, 'Perspectives on Australian Foreign Policy, 2001', Australian Journal of International Affairs, 56 (1) 2002, pp.47-63.

${ }^{3}$ On elements of this dynamic within Europe, for example, see A. Geddes, The Politics of Migration and Immigration in Europe (London: Sage, 2003).

${ }^{4}$ K. Booth, 'Security and Emancipation', Review of International Studies, 17 (2), 2001, pp. 313-326.

${ }^{5}$ See, for example, M. McDonald, 'Human Security and the Construction of Security', Global Society. 16 (3) 2002, pp.277-295. My use of the term 'discourse' here combines approaches that conceive discourses as explanatory/ interpretive tools (J. Dryzek, The Politics of the Earth: Environmental Discourses (Oxford: Oxford University Press, 1997), p.8) with those that define discourses as ultimately performing political functions (M. Foucault, Discipline and Punish: The Birth of the Prison (New York: Vintage, 1977), p.27). A discourse of security, therefore, provides a basis both for interpreting world events and for conditioning the way actors go about attaining or maintaining security.

${ }^{6}$ S. Walt, 'Renaissance of Security Studies', International Studies Quarterly, 35, 1991, pp.211-239; S. Lynn-Jones, 'The Future of International Security Studies', in D. Ball and D. Horner (eds.), Strategic Studies in a Changing World: Global, Regional and Australian Perspectives (Canberra: Strategic and Defence Studies Centre, 1992).

${ }^{7}$ Booth, 'Security and Emancipation'; R. Wyn Jones, Security, Strategy and Critical Theory (Boulder, Colorado: Lynne Reinner, 1999). The use of capital letters for 'Critical Security' is to differentiate the Welsh School discourse of Critical Security (to which I primarily refer) from broadly critical approaches to security in international relations. On the related distinction between critical theory and Critical Theory in
} 
international relations, see C. Brown, 'Turtles all the Way Down: Antifoundationalism, Critical Theory and International Relations’, Millennium. 23 (2), 1994, p.214.

${ }^{8}$ O. Wæver, 'Securitization and Desecuritization', in R. Lipschutz (ed.), On Security (New York:

Columbia UP, 1995).

${ }^{9}$ W. Maley, 'Asylum-seekers in Australia's international relations', Australian Journal of International Affairs, 57(1), 2003, pp.187-202; D. McMaster, 'Asylum-seekers and the insecurity of a nation', Australian Journal of International Affairs, 56 (2), 2002, pp.279-290.

${ }^{10}$ Maley, 'Asylum-seekers', p.193.

${ }^{11}$ K. Fierke, 'Changing Worlds of Security', in K. Krause and M. Williams (eds.), Critical Security Studies (London: UCL, 1997); D. Bigo, 'Security and immigration: Toward a critique of the governmentality of unease', Alternatives: Global, Local, Political, 27 (1), Jan-March 2002, pp.63-92.

${ }^{12}$ A. Gramsci in J. Buttigieg (ed), Prison Notebooks, Vol.1 (New York: Columbia UP, 1992); Foucault, Discipline and Punish.

${ }^{13}$ On the basis of state power in this context, for example, see J.Weldes et al., 'Introduction: Constructing Insecurity', in Weldes et al. (eds.), Cultures of Insecurity (Minneapolis: University of Minnesota Press, 1999), pp.17-21.

${ }^{14}$ R. Walker, Inside/ Outside: International Relations as Political Theory (Cambridge: Cambridge UP, 1993).

${ }^{15}$ M. Shapiro, 'Strategic Discourse/ Discursive Strategy: The Representation of 'Security Policy' in the Video Age', International Studies Quarterly, 34, 1990, pp.327-340; S. Dalby, Creating the Second Cold War (London: Pinter, 1990); E. Kolodziej, 'Renaissance in Security Studies? Caveat Lector!' International Studies Quarterly. 36 (4), 1992, pp.421-38; D. Campbell, 'Violent Performances: Identity, Sovereignty, Responsibility', in Y. Lapid and F. Kratochwil (eds.), The Return of Culture and Identity in IR Theory (Boulder, Colorado: Lynne Reinner, 1996); S. Smith, 'The Increasing Insecurity of Security Studies', Contemporary Security Policy, 20 (3), 1999, pp.72-101.

${ }^{16}$ On this latter point see, for example, P. Katzenstein (ed.), The Culture of National Security (New York: Columbia, 1996).

${ }^{17}$ Dalby, Creating the Second Cold War, p.13.

${ }^{18}$ M. Barnett, 'Culture, Strategy and Foreign Policy Change: The Road to Oslo', European Journal of International Relations, 5 (1), 1999, pp.5-36.

${ }^{19}$ Although this need not always be the case, as the analysis of Australia's approach to asylum-seekers will demonstrate.

${ }^{20}$ L. Wittgenstein, Philosophical Investigations (Oxford: Basil Blackwell, 1958); J. Searle, The Construction of Social Reality (New York: Free Press, 1995). For excellent overviews of the role of language in the construction of social reality in international relations, see T Riise, '”Let's Argue!" Communicative Action in World Politics', International Organization, 54 (1), 2000, pp.1-39; and K. Fierke, 'Links Across the Abyss: Language and Logic in International Relations', International Studies Quarterly, 46, 2002, pp.331-54.

${ }^{21}$ J. Milliken, 'The Study of Discourse in International Relations: A Critique of Research and Methods', European Journal of International Relations, 5 (2), 1999, p.236.

${ }^{22}$ Fierke, 'Links Across the Abyss', p.349.

${ }^{23}$ Barnett ('Culture, Strategy and Foreign Policy Change') provides an excellent example of the processes through which political leaders might go about creating opportunities for particular security conceptions and practices to attain support from their domestic population.

${ }^{24}$ M. Dillon, The Politics of Security (London: Routledge, 1996).

${ }^{25}$ On these points, see Walker, 'The Subject of Security', in Krause and Williams (eds.); and Burke, In Fear of Security: Australia's Invasion Anxiety (Sydney: Pluto, 2001). A range of critical and poststructuralist security theorists have pointed to the politics of security in this context. See, for example, Dalby, Creating the Second Cold War; Shapiro, 'Strategic Discourse/ Discursive Strategy'; D. Campbell, Writing Security (Minneapolis: University of Minnesota Press, 1992); Dillon, Politics of Security; and C. Constantinou 'Poetics of Security', Alternatives: Global, Local, Political, 25, 2000, pp.287-306.

${ }^{26}$ G. Cheeseman, 'Facing an Uncertain Future: Defence and Security under the Howard Government', in J. Cotton and J. Ravenhill (eds.), The National Interest in a Global Era: Australia in World Affairs, 19962000 (Melbourne: Oxford University Press, 2001), p.202.

${ }^{27}$ Cheeseman, 'Facing an Uncertain Future', p.206. 
${ }^{28}$ G. Evans and B. Grant, Australia's Foreign Relations in the World of the 1990s (Melbourne: Melbourne UP, 1995).

${ }^{29}$ Burke, In Fear of Security, p.195.

${ }^{30}$ Cheeseman, 'Facing an Uncertain Future', p.209.

${ }^{31}$ Burke, In Fear of Security, pp.181-222.

${ }^{32}$ G. Smith and S. Kettle (eds.), Threats Without Enemies: Rethinking Australia's Security (Sydney: Pluto, 1992); G. Cheeseman and R. Bruce (eds.), Discourses of Danger and Dread Frontiers: Australian Defence and Security Thinking After the Cold War (Sydney: Allen and Unwin, 1996).

${ }^{33}$ Burke, In Fear of Security. This has been applied in particular to Australia's conception of the region, and narratives of identity that have encouraged positioned (white) Australia as in need of protection from an ethnically and culturally different region.

${ }^{34}$ Department of Foreign Affairs and Trade (DFAT), In the National Interest: Australia's Foreign and Trade Policy White Paper (Canberra: Commonwealth of Australia, 1997), pp.iii-viii; DFAT, Advancing the National Interest: Australia's Foreign and Trade Policy White Paper (Canberra, Commonwealth of Australia, 2003), pp.vii-viii.

${ }^{35}$ McMaster, 'Asylum-seekers’, p.280.

${ }^{36}$ Bigo, 'Security and Immigration'.

${ }^{37}$ K. Murphy and K. Towers, 'Attacks taint refugee saga', Australian Financial Review. 14 September, 2001, p.3; M. Barton, 'Terror threat is real- Howard', The West Australian. 20 September, 2001.

${ }^{38}$ In F. Kelly, 'Tampa asylum seekers caught in political deadlock'. The 7.30 Report, 30 August, 2001. (www.abc.net.au/7.30/content/2001/s355371.htm).

${ }^{39}$ In Burke, In Fear of Security, p.322.

${ }^{40}$ In Murphy and Towers, 'Attacks taint refugee saga', p.3.

${ }^{41}$ In Maley, 'Asylum-seekers', p.193. The leading figure in the push for the establishment of a federal Australian state, Henry Parkes, spoke in the late 1880s of the threat posed by 'the countless millions of inferior members of the human family who are within easy sail of these shores'. In Burke, In Fear of Security, p.15.

${ }^{42}$ In Murphy and Towers, 'Attacks taint refugee saga', p.3.

${ }^{43}$ In Australian Associated Press (AAP), 'Illegal boats could be a pipeline for terrorists: Reith', Australian Associated Press. 15 September, 2001.

${ }^{44}$ In AAP, 'Govt continues linking refugees to terrorists', Australian Associated Press. 20 September, 2001.

${ }^{45}$ In AAP, 'Howard says need to redouble border checks', Australian Associated Press. 21 September, 2001.

${ }^{46}$ In Barton, 'Terror threat', 2001.

${ }^{47}$ Maley, 'Asylum-seekers', pp.191-193.

${ }^{48}$ A. Nadig, 'Human Smuggling, National Security, and Refugee Protection', Journal of Refugee Studies, 15 (1), 2002, pp.1-25.

${ }^{49}$ McMaster, 'Asylum-seekers', p.287.

${ }^{50}$ Commonwealth of Australia, House of Representatives Hansard. 20 September, 2001, p.31116.

${ }^{51}$ Wesley, 'Perspectives on Australian Foreign Policy'; T. Kevin, 'Australian foreign policy at the crossroads', Australian Journal of International Affairs, 56 (1), 2002, pp. 31-37.

${ }^{52}$ Commonwealth of Australia, Senate Hansard. 24 September, 2001, p.27731.

${ }^{53}$ Maley, 'Asylum-seekers', p.193; Edmund Rice Centre, 'Debunking the Myths about Asylum Seekers'. November 2001. (http://www.erc.org.au/just_comments/1029891642.shtml).

${ }^{54}$ Commonwealth of Australia, Senate Hansard. 24 September 2001, p.27702.

${ }^{55}$ Such a criticism evokes concerns elaborated by Copenhagen School theorists, namely that 'securitizing' particular issues demonstrates a failure of the political process to deal with these issues effectively, encouraging what Buzan et al. describe as 'panic politics'. B. Buzan, O. Wæver and J. de Wilde, Security: A New Framework for Analysis (Boulder, Colorado: Lynne Reinner, 1998), p.34.

${ }^{56}$ In Maley, 'Asylum-seekers', p.193.

${ }^{57}$ In Wesley, 'Perspectives on Australian Foreign Policy’, p.58.

${ }^{58}$ Commonwealth of Australia, House of Representatives Hansard. 19 September, 2001, p.30975.

${ }^{59}$ In M. Seccombe, 'Politics of fear works well for PM', Sydney Morning Herald. 19 September, 2001, p.8.

${ }^{60}$ Commonwealth of Australia, Senate Hansard. 24 September, 2001, p.27702. 
${ }^{61}$ J. Bially Mattern ‘The Power Politics of Identity’, European Journal of International Relations, 7 (3), 2001. p.351.

${ }^{62}$ Defence Minister Peter Reith later acknowledged that this claim was false. See Maley, 'Asylum-seekers', p.193. A Defence liason officer also claimed in 2004 that he had informed Prime Minister Howard at this time that there was no evidence to support the story that asylum-seekers had thrown children overboard. ABC, 'Howard pressured over 'children overboard' knowledge', Lateline programme, 16 August, 2004. (www.abc.net.au/lateline/content/2004/s1177964.htm).

${ }^{63}$ ie that they had not waited at refugee processing camps in their countries of origin, unlike other asylumseekers. This characterisation, aside from being questionable as a description of the process of seeking asylum in states such as Afghanistan and Iraq, is important in the Australian context given the traditional primacy of egalitarian ideals in most narratives of Australian identity. This representation could therefore be viewed as attempting to portray asylum-seekers as others and as different from Australians in fundamental ways. On asylum-seekers as ‘queue jumpers' see K. Gelber, ‘A fair queue? Australian public discourse on refugees and immigration', Journal of Australian Studies, 77, 2003, pp.23-30.

${ }^{64}$ ABC, 'Ashmore off limits', Media Watch. 10 May, 2004. (www.abc.net.au/mediawatch/transcripts/s1105289.htm).

${ }^{65}$ A. Hopkins, 'Boat people are campaign fodder in Australia', Reuters News. 7 October, 2001.

${ }^{66}$ C. Williams, 'Australian security policy, post-11 September', Australian Journal of International Affairs, 56 (1), 2002, pp.13-21. Wesley, 'Perspectives on Australian Foreign Policy'.

67 Maley, 'Asylum-seekers'; Commonwealth of Australia, Senate Hansard. 24 September 2001, p.27731.

${ }^{68}$ McMaster, ‘Asylum-seekers', p.286 (my emphasis).

${ }^{69}$ In M. Gordon, 'Why Incumbency is Such a Big Factor for the Caretaker', The Age. 6 October, 2001, p.5. Although significantly, Prime Minister Howard stated in the lead up to the 1998 federal election that Australia faced a 'very turbulent and hostile (security) environment', in this context in the wake of the Asian financial crisis. In Burke, In Fear of Security, p.185.

${ }^{70}$ Williams, ‘Australian security policy', pp.15-17.

${ }^{71} \mathrm{~J}$. Camilleri, 'A leap into the past- in the name of the national interest', Australian Journal of International Affairs, 57 (3), 2003, p.436.This is also significant given that, as a number of commentators have argued, the treaty's central (if not exclusive) focus was on conflict in the Pacific region. Camilleri, 'A leap into the past', p.436; G. Barker, 'The Boat Comes in for John Howard', Australian Financial Review. 15 September, 2001, p.25.

${ }^{72}$ In M. Riley and G. Alcorn. 2001. 'US armed with \$40b war chest', The Age. 15 September, 2001, p.1.

${ }^{74}$ In Wesley, 'Perspectives on Australian foreign policy', p.60.

${ }^{74}$ Camilleri argues that under Howard, 'The US alliance has been embraced with a consistency and enthusiasm unmatched by any other ally of the United States, the United Kingdom included, and, the historical record might in due course show, by any previous Australian government...' 'A leap into the past’, p.435.

${ }^{75}$ Williams, 'Australian security policy', p.17.

${ }^{76}$ In M. Davis, 'Defence Spending will rise: PM', Australian Financial Review. 24 October, 2002, p.13. The Howard government also portrayed controversial anti-terror legislation post-September 11 and Bali as necessary, despite arguments of the potential threats this legislation posed to civil liberties within Australia. J. Grubel, 'Government says it won't interfere with civil liberties', Australian Associated Press. 16 October, 2002; J. Hocking, Terror laws: ASIO, counter terrorism and the threat to democracy (Sydney: UNSW Press, 2004).

${ }^{77}$ Camilleri argues that the government had decided to deploy troops to assist the US in Iraq as early as mid-2002. 'A leap into the past', p.441.

${ }_{78}^{7 n}$ M. Moore, 'Vaile spurned on Iraq comments', Sydney Morning Herald. 11 March, 2003, p.9.

${ }^{79}$ This was particularly evident in the 2003 Department of Foreign Affairs and Trade (DFAT) White Paper, produced one month before Australia's official commitment to the war in Iraq. It argued that 'Saddam Hussein's virulent anti-Western stance and his support for terrorism raise the possibility of his making available weapons of mass destruction to al-Qaida or other terrorist groups'. DFAT, Advancing the National Interest: Australia's Foreign and Trade Policy White Paper (Canberra: Commonwealth of Australia, 2003), p.44.

${ }^{80}$ In M. Riley et al., 'PM unrepentant on Bali link', Sydney Morning Herald. 11 March, 2003, p.9. 


\footnotetext{
${ }^{81}$ Foreign Minister Alexander Downer argued after the Iraq intervention that support for the US position on Iraq was necessary for achieving Australian security, noting that 'it wasn't a time in our history to have a great and historic breach with the United States. If we were to walk away from the American alliance it would leave us as a country very vulnerable and very open...'. In T. Allard, 'Going to war secured US alliance, says Downer', Sydney Morning Herald. 3 March, 2004, p.3.

${ }^{82}$ Williams, 'Australian security policy’, p.16.

${ }^{83} \mathrm{~J}$. Verrier, 'Australia's self-image as a regional and international security actor: some implications of the Iraq war', Australian Journal of International Affairs, 57 (3), 2003, pp.455-471; Camilleri, 'A leap into the past’; G. Kitney, 'Without extreme prejudice’, The Sydney Morning Herald. 8 November, 2002, p.15.

${ }^{84}$ D. Kingsbury, 'After the Bali Cocoon Falls Away', The Age. 25 September, 2003, p.15. I am indebted to one of the anonymous reviewers on this point.

${ }^{85} \mathrm{~J}$. George, 'Will the chickenhawks come home to roost? Iraq, US preponderance and its implications for Australia', Australian Journal of International Affairs, 57 (2), 2003, pp.235-242; Williams, 'Australian security policy'.

${ }^{86}$ Commonwealth of Australia, House of Representatives Hansard. 19 September, 2001, p.30992.

${ }^{87}$ George, 'Will the chickenhawks?', p.237.

${ }^{88}$ Riley et al., 'PM unrepentant', p.9.

${ }^{89}$ Seccombe, 'Politics of fear', p.8.

${ }^{90}$ In AAP, 'Shocked Howard vows steely pursuit of terrorists', Australian Associated Press. 19 October, 2002.

${ }^{91}$ In S. Dunlevy, 'We are at greater risk now than ever- PM', Daily Telegraph. 16 October, 2002, p.8.

${ }^{92}$ National polls indicated that Australians were split in their support for Australian involvement in the war in Iraq with UN approval, but were strongly opposed to Australian involvement without it. Nespoll,

'Australia Day Poll'. 27 January, 2003.

(www.newspoll.com.au/image_uploads/cgi-lib.2317.1.0102ausday_poll.pdf).

${ }^{93}$ In D. Shanahan, 'Howard joins the attack on Paris', The Australian. 15 March, 2003, p.1.

${ }^{94}$ In P. Starick, 'In war, remember Bali, PM says', Adelaide Advertiser. 10 March, 2003, p.1.

${ }^{95}$ In P. Hudson and C. Overington, 'Howard links Iraq war to Bali', The Age. 10 March, 2003, p.1.

${ }^{96}$ Surveys indicated that up to $76 \%$ of Australians opposed intervention in Iraq at the time of Australia's official commitment of troops, while large protests occurred throughout major Australian cities to oppose the government's stance. Nespoll, 'Australia Day Poll'.

${ }^{97}$ Shanahan noted that support for the war reached $50 \%$ by the $5^{\text {th }}$ day of conflict in Iraq. D. Shanahan, ‘50\% now back PM’s war', The Australian. 25 March, 2003, p.1.

${ }^{98}$ D. Shanahan, 'Public opinion swings behind PM', The Australian. 22 March, 2003, p.7; West Australian. 2003. 'Don’t encourage war disunity', The West Australian. 22 March, 2003.

99 'Public opinion', p.7.

${ }^{100}$ Specifically regarding changes to legislation governing temporary protection visas for asylum-seekers. Department of Immigration, Multicultural and Indigenous Affairs, Measures for Temporary Protection and Temporary Humanitarian Visa Holders. 2004. (http://www.immi.gov.au/refugee/tpv thv/index.htm).

${ }^{101}$ In Allard, 'Going to War', p.3.

${ }^{102}$ In the lead up to the Australian election, the main opposition part broadly supported the government's stance on the Tampa issue, while prominent figures in the Australian media echoed the government's view that the events of Bali, for example, left Australia with no choice but to commit itself whole-heartedly to the American-led war on terror. See, for example, G. Sheridan, 'A Nation Built on Common Sense', The Australian. 16 October, 2003.

${ }^{103}$ See, for example, Maley, 'Asylum-seekers'; and McMaster, 'Asylum-seekers'.

${ }^{104}$ See Verrier, 'Australia's self-image'; George, 'Will the chickenhawks?’; and M. Davis, ‘Terror fight has put us more at risk, says ASIO', Australian Financial Review. 25 October, 2002, p.16.

${ }^{105}$ Seccombe, 'Politics of Fear'; Commonwealth of Australia, Senate Hansard. 24 September 2001, p.27702.

${ }^{106}$ For example, RN Berki, Security and Society (London: JM Dent, 1986).
} 